\title{
The Influence of Music as a Key Element of Sales Promotion
}

\author{
Shaip Bytyçi
}

\begin{abstract}
Visual factors such as exposure, colors, fragrance, music for sale, are a way of communicating between buyers and sellers, which influence consumer decision-making in buying and selling or can also be referred to as a face-to-face deal designed to influence in the decision of a group of persons or a single person to make a purchase. Music as a powerful tool can offer great sales by making consumers feel positive, secure and happy in their purchases. Buyers also consider music to be a personal connection that affects the emotions and mood of the buyer, the genre of music released in the store has an effect on how the shopper views himself in the social environment and in the end it has an effect on the relaxation and mood of the buyer. The combination of genre, tempo, sound and a combination of (recent and old) musical hits enable sales to increase as consumers tend to stay in the market longer until the end of their favorite song, in the meantime during the attitude he puts in his basket unplanned things influenced by the background music, on the other hand the combination of the right colors provides a boost in sales. The purpose of this research is to recognize the influence of different genres of music on the concentration of purchases. By gathering information through research from various literatures, through respondents who frequent shopping malls and follow the various offers the paper comes with some conclusions and recommendations
\end{abstract}

Index Terms - Consumer, Emotions, Marketing, Music

\section{INTRODUCTION}

People who tend to make unplanned purchases spend more when music is present, while dreamy shoppers buy less than usual when the music is released. A study by Morrin (2005), the APA's 2005 annual convention has led that all types of buyers, buy more in the presence of music, probably due to overloads during the day. Buyers who purchased unplanned products spent, on average, \$32.89 more when the music was released than when the music was not released.

Ford (2013) proposes that there are 3 (three) qualities of music that influence buyer behavior about shopping in an environment and they are: tempo, volume and genre. The individual effects of each will be seen below, which are explained by Mehrabian (1980, pp. 39-53) (The Model of Pleasure, Awakening and Domination - PAD). And almost at the basic level, this model shows that an environment can change individual mood.

Milliman (1982) has completed a study in the city of New York at a grocery store, investigating the effects of the tempo of music on customer behavior. The design was very

Published on March 14, 2020.

Shaip Bytyçi, AAB College, Pristina, Kosovo.

(e-mail: shaip.bytyqi@universitetiaab.com) simple but the results were very important: Slow music (shopper spends more time in store and 32\% sales growth) comparing when there was fast music playing in the store. All of these effects can best be explained by the PAD model: Fast music leads you through high levels of arousal. The effects of tempo are also explored in a family-run restaurant by Caldwell and Hilbert (1999). Slow music has caused customers to spend huge amounts of alcohol and spending more time eating, while fast music sends them to fast food and less time to spend. As can be seen, each of these effects may be needed in a different restaurant. When choosing music that have an impact on consumers, rhythm and tempo are easiest to control buyers. Research has shown that slower and lighter music causes shoppers to spend more time thinking about shopping and enjoying the atmosphere, also boosting sales.

The fast tempo and high volume make consumers look at products and get out of the store faster. High volume of sound is in most cases a bad thing. For effective sales and sales growth, the volume of music needs to be in order for the buyer to be able to think about buying and the choices he or she is thinking of making. A study in 2013 by Myriam V.Thoma has shown that loud music is a bad turnaround for consumers because it has caused them stress in the psychological system. The conclusion was that during the study of 60 women, the average age of 25 years with relaxing music: the sound of the waterfall flowing, the result was clear.

Using the model (PAD, pattern of behavior,is easy to understand because the loud sound signal in the human brain increases stress and can affect the response of the consumer (buyer).

\section{LITERATURE REVIEW}

Smith and Curno (1966) realized that loud music had a direct effect on the time spent in the store. More precisely, loud music sends you in the absence of time for shopping compared to loud music. Despite this fact, the difference in the number of sales was not statistically significant. From further research suggests that loud music can send you to a distorted perception of how much time has passed, but the effect is greater genders. Loud music causes women to think that there's less time spent since it is the opposite.

Another study by Yalch and Spangenber (1990) proved that age plays a role in the sound effects of music. Younger buyers spend more time shopping when music is released in a prominent place as a priority; while older shoppers spend more time shopping when music is released in the background meaning not much is heard.

They proved that using the sound of music to influence the consumer or the buyer must be adapted because a tactic 
may not be appropriate for all ages.

The music genre has an effect on sales, a research study on the effects of the 40-song top list Pop list versus Classical music at a wine shop. It has been proven that in the wine shop, classical music has had an effect on sales by buyers, where buyers have not bought many wines but have chosen the more expensive ones.

Another study has shown that, during the holiday and holiday season, shoppers buy more products when the holiday song is released in-store. From these studies, it seems that the type of music released sends a signal about what products to buy.

Customers who listen to the music they like seem like a good experience, even though they are waiting in line or waiting to talk to customer service. When people are enjoying or listening to the music they like no matter what they decide: that time automatically becomes more important that brings pleasure. In short, it doesn't matter to consumers if they wait a little longer, as that store is launching valuable music for them. Music emits dopamine at the center of the brain (Carter, 2016). This is also the strategic reason for finding music that fits and is exciting for shoppers at the time of purchase. Listening to music releases dopamine, and dopamine increases happiness. People also love music because they can express their personality and thoughts through the music they hear and can often relate song lyrics to experiences in their lives.

Music is the tool that controls sales; it can empower consumers to feel positive, confident and happy in their purchases just by choosing the right music. By combining genre, tempo, sound and the combination of music with a perfect choice, the retailer has the power to grow and win the majority of customers passing by.

Music has been used in consumer behavior research as well as in the field of communication, psychology and music therapy to determine its effects on behavior, preference, and mood (Gorn, 1982). Research into the investigation of musical effects can be divided into those that analyzed and manipulated the structural and sound elements of music as well as those that did not. Structural elements refer to properties that make up musical sounds such as melody, rhythm, harmony, big or small mode, dynamics and tempo. Structural elements refer to properties that make up musical sounds such as melody, rhythm, harmony, big or small mode, dynamics and tempo. As civilization has grown, the purpose of music in human life has changed, but it has an effect on the brains of consumers.

Sellers with good knowledge of the music of note that has an impact on the behavior of buyers and has the effect that a break in the human brain. Over the years, a large number of studies have been done to see how different genres of music have influenced the market. Everything about music, sound and tempos all play an important role in how consumers spend their money in various stores. Selecting the right music for any store is not an easy task than you might think, it takes some art to optimize the music for the purpose of selling to reach and suit everyone. You first need to determine the type of store you want to be represented and how you want customers to feel while they are buying the product and after; there are many other variables that affect how the time of day is (ideally) and what is offered in the sale (discount).

A study of the effect of music on the market of selling or trading behavior (Donovan \& Rossiter, 1982) is also known as the model: PAD (pleasure, awakening and domination).

Studies have shown that the atmosphere of the store affects the emotional state of customers.

For example: In-store music volume, tempo, rhythm, lyrics and special songs (which may be outdated or hits) where consumers have rated their songs as singles based on their listening. Studies show that shop owners appeal to find adequate music that brings pleasure to the buyer and awakens feelings that can positively influence the buyer, where the impact is on the buyer as well as the emotional state of that buyer. (Awakens adrenaline and relieves stress and influences shoppers to drive sales in different ways).

According to publications in 2013 by Thomas Schafer, explained how previous research categorized music as having an impact on four psychological categories or four dimensions: social, emotional, arousal, and cognitive (Schäfer, Sedlmeier, Städtler, \& Huron, 2013). Socialthemed music causes shoppers to think about their role in society and introduce themselves. Emotional music calls on the listener (buyer in this case) to feel something: joy, despair, anger and adrenaline. Music with meaning or cognitive function allows people to feel alienated from the world or vice versa to feel engaged in the world around them arousal-focused music makes shoppers in action (listening). The genre of music released in the store has an effect on how the shopper views himself in the social environment and ultimately has an effect on the shopper's relaxation and humor.

Choosing music for sale means sending the right message to the buyer, the seller wants the buyer to feel positive and confident in the choice of purchase or product, living the present situation and being happy with the purchase. Coordinating the four influential functions: emotional, cognitive, social, and arousal are the best way to bring shoppers closer to the points of sale so they can feel positive about the experience gained.

\section{RESEARCH METHODOLOGY}

The basis for this research is to collect data through questionnaire with respondents who apply or will begin to apply music as a key element in driving sales to Kosovo's target consumer groups. We also consulted relevant literature in the related field. The beginning of this study has been discussed with relevant experts in the field prior to the questionnaire design phase. The survey was conducted in January 2020. We surveyed 120 respondents through a questionnaire that had 17 questions about the impact of music. The data processing and presentation method was done by collecting the results that were processed through the Excel program (first and second methods) and the third way, cross-tabulated, through the SPSS Statistical Package for Social Sciences. 


\section{RESEARCH RESULTS AND DISCUSSIONS}

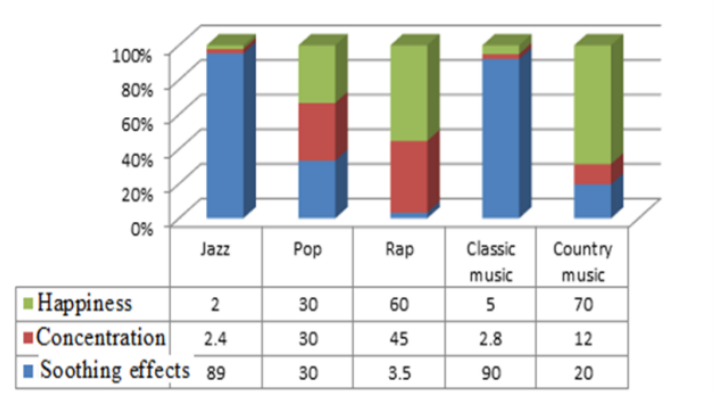

Graph 1: Effect of different genres of music on consumer concentration

Respondents to the question how the effect of different genres of music on consumer concentration, according to the types of music by presenting three components of consumer sentiment, obtain the data by $\%$ presented in graph number



Graph. 2: Music genre and productivity growth in businesses

When asked how selecting a genre of music would affect job productivity growth, respondents present data based on their experience, without going into in-depth analysis or browsing any relevant literature. These data, based on their experience and application at different points of sale.

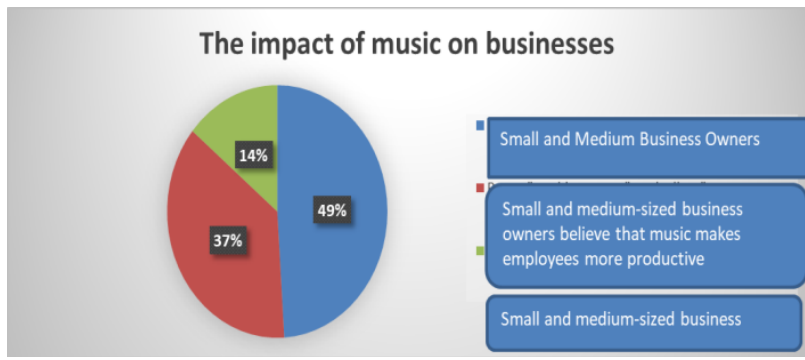

Graph 3: The impact of music on businesses

In most of the enterprises of different activities, different types of music are used, depending on the types of enterprises, region and time periods. The survey was conducted for small and medium-sized businesses.

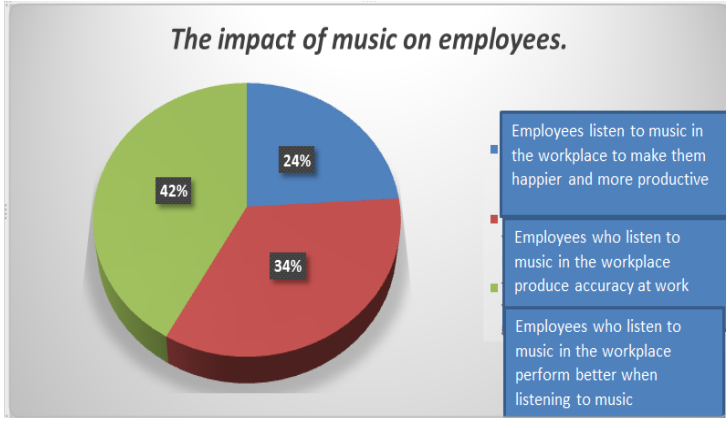

Graph. 4 The impact of music on employees.

Music has the ability to influence the way we experience things around us, and happy tunes can make the work more enjoyable. If you listen to music at work, you are in good company. In fact, $24 \%$ of employees listen to music at work to make them happier and more productive. And according to research, it works! Studies show that $42 \%$ of workers perform better when listening to music and $34 \%$ of employees produce more accurate work when listening to music. Listening to music not only enhances workplace efficiency but can also improve your mental and emotional well-being.

\section{CONClusion}

The most important qualities of music that influence a buyer's behavior about shopping in an environment are: tempo, volume, and genre. Tempo: Slow music has caused customers to spend huge amounts on alcohol and spending more time eating, while fast music orients them to fast food and less time to spend.. Volume or sound: Loud music sends you in the absence of time for shopping compared to loud music. From further research suggests that loud music can send you to a distorted perception of how much time has passed, but the effect is greater genders: Loud causes women to think that there's less time spent while the opposite. The genre: It has been proven that in the wine shop, classical music has had an effect on sales by buyers, where buyers have not bought many wines but have chosen the more expensive ones, where it has been proven that the music genre has an effect on sales. Music has an impact on four psychological categories or four dimensions: social, emotional, arousal and cognitive. Social-themed music causes shoppers to think about their role in society and introduce themselves; Emotional music calls on the listener (buyer in this case) to feel something: joy, despair, anger, and adrenaline; Music with cognitive meaning or function allows people to feel alienated from the world or vice versa to feel engaged in the world around them; Awakeningfocused music gets shoppers into action (listening). Overall results showed that shoppers as well as workers consider music a personal bond that influences shoppers' emotions and humor. Whereas the psychology of colors is based on mythical theories and reflections on the emotional and mental effects of color, positive and negative.. 


\section{REFERENCES}

[1] Aromatherapist, T. E. (2016, October 20). WHAT IS SCENT MARKETING? Retrieved from THE ENGLISH AROMATHERAPIST: http://englisharomatherapist.com/what-isscent-marketing.

[2] Bradley, J. (n.d.). Social Factors in Marketing That Influence Products. Retrieved from Chron https://smallbusiness.chron.com/social-factors-marketing-influenceproducts-56553.html.

[3] Caldwell, C., \& Hibbert, S. A. (1999). Play That One Again: the Effect of Music Tempo on Consumer Behaviour in a Restaurant. European Advances in Consumer Research, 58-62.

[4] Campbell, J. (2008, June 22). Color Psychology In Marketing. Retrieved from Brandin Strategy Insider: https://www.brandingstrategyinsider.com/colorpsycholog/\#.XkqsCzJKjDc

[5] Canty, E. (2016, May 4). The effect different genres of music can have on your mind, body, and community. Retrieved from UPWORTHY: https://www.upworthy.com/the-effect-differentgenres-of-music-can-have-on-your-mind-body-and-community

[6] Aromatherapist, T. E. (2016, October 20). WHAT IS SCENT MARKETING? Retrieved from THE ENGLISH AROMATHERAPIST: http://englisharomatherapist.com/what-isscent-marketing/

[7] Bradley, J. (n.d.). Social Factors in Marketing That Influence Products. Retrieved from Chron: https://smallbusiness.chron.com/social-factors-marketing-influenceproducts-56553.html

[8] Caldwell, C., \& Hibbert, S. A. (1999). Play That One Again: the Effect of Music Tempo on Consumer Behaviour in a Restaurant European Advances in Consumer Research, 58-62.

[9] Campbell, J. (2008, June 22). Color Psychology In Marketing. Retrieved from Brandin Strategy Insider: https://www.brandingstrategyinsider.com/colorpsycholog/\#.XkqsCzJKjDc

[10] Canty, E. (2016, May 4). The effect different genres of music can have on your mind, body, and community. Retrieved from UPWORTHY: https://www.upworthy.com/the-effect-differentgenres-of-music-can-have-on-your-mind-body-and-community

[11] Carter, E. (2016). Whistle While You Work: Impact of Music on Productivity [Infographic]. Retrieved from WebFX https://www.webfx.com/blog/internet/music-productivity-infographic/

[12] Ciotti, G. (n.d.). The Psychology of Color in Marketing and Branding. Retrieved from HelpScout: https://www.helpscout.com/blog/psychology-of-color/

[13] Donovan, R., \& Rossiter, J. (1982). Store atmosphere: an environmental psychology approach. Journal of Retailing, 34-57.

[14] Duka, A. X., \& Pano, N. (1999). Promocioni. Tiranë: SHBLU.

[15] Ford, M. (2013, June 15). The Psychology of Music: Why Music Plays a Big Role in What You Buy. Retrieved from MotiveMetrics Research: http://blog.motivemetrics.com/The-Psychology-of-MusicWhy-Music-Plays-a-Big-Role-in-What-You-Buy

[16] Glen, J. (n.d.). Advertising vs. Marketing. Retrieved from BusinessDictionary:

http://www.businessdictionary.com/article/1094/advertising-vsmarketing-d1412/

[17] Glen, J. (n.d.). Marketing vs. Sales. Retrieved from BusinessDictionary: http://www.businessdictionary.com/article/1087/marketing-vs-salesd1412/

[18] Gorn, G. J. (1982). The Effects of Music in Advertising on Choice Behavior: A Classical Conditioning Approach. Jorunal of Marketing, 94-101.
[19] Herz, R. (2007). The Scent of Desire: Discovering Our Enigmatic Sense of Smell. HarperCollins.

[20] Kolowich, L. (2017, November 3). Color Psychology in Marketing [Infographic]. Retrieved from HubSpot: https://blog.hubspot.com/marketing/psychology-of-color

[21] Kotler, P., \& Armstrong, G. (2013). Parimet e marketingut. Tiranë: UETPress.

[22] Madzharov, A. V., Block, L. G., \& Morrin, M. (2015). The cool scent of power: Effects of ambient scent on consumer preferences and choice behavior. Journal of Marketing, 83-96.

[23] Mehrabian, A. (1980). Basic dimensions for a general psychological theory: Implications for personality, social, environmental, and developmental studies. Cambridge: Oelgeschlager, Gunn \& Hain.

[24] Milliman, R. (1982). Using the Background Music to Affect the Behavioor of Supermarket Shoppers. The Journal of Marketing, 46(3).

[25] Morrin, M. (2005). Music motivates impulse buyers, not thoughtful shoppers. Monitor on Psychology, 17.

[26] Russell, E. (2009). The Fundamentals of Marketing. Lausanne, Switzerland: Bloomsbury Publishing PLC.

[27] Schäfer, T., Sedlmeier, P., Städtler, C., \& Huron, D. (2013). The psychological functions of music listening. Frontiers in Psychology, 511.

[28] Yalch, R., \& Spangenberg, E. (1990). Effects of Store Music on Shopping Behavior. Journal of Consumer Marketing, 55-63.

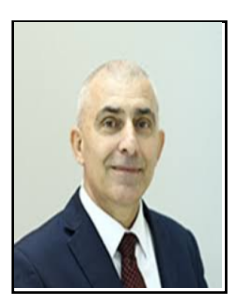

Professor Doctor Shaip Bytyçi from Ksovo, Actually is Dean of Faculty of Economics, AAB College, Kosovo ,Pristina. Bytyçi is lecturer of marketing subjects in bachelor and master studies, Supervises research work at master's level. Bytyçi PhD Degree: Doctor of economic science, (Dr.Sc) Thesis: "Management - implementing marketing service activities in Kosovo" Faculty of Tourism and Hospitality, University SV. Kliment Ohridski. Bitola (2007 - 2010), Master Degree: Master of Economic Sciences (Msc) Thesis: The Role of Marketing in an Enterprise, I.E. In The „Mabetex” Enterprise, Faculty of Economics, Pristina University, Bachelor Degree: Economy and Enterprise, Faculty of Economics, Pristina University

2016- continues Dean of the of the Faculty of Economics; AAB College, 2005 - 2016 Vice Dean of the of the Faculty of Economics; AAB College 2005 -- continues Lecturer, AAB College, Pristina, Kosovo, 2017 continues, Chairman of the Board, AAB Institute of Accounting and Auditing, 2018 - continues Real Estate Appraiser, Ministry of Finance, R. Kosovo, $2017-2018$ Visiting professor, University of Alexander Moisiu, Durres, Albania, 2012 - 2013, Visiting professor; FON University, Northern Macedonia, 2011 - 2012, Visiting professor; State university of Tetov, Northern Macedonia, 2005 - 2016, Visiting professor; University of Pristina, Faculty of Natural Sciences, Kosovo. He's published articles: "Photography as a key element in tracking message to targeted customer Groups" at Eco forum Journal , Vol 8, No 1 (2019), http://www.ecoforumjournal.ro/index.php/eco/article/view/875, also he is author of the article "The Impact of Product Exposure as a Key Element of Sales Promotion" International Editorial and Advisory Board, 2018, European Journal of Economics and Business Studies, 2018 The International Institute for Science, Technology and Education (IISTE) 2018-08-01 ,also he he published the article entitled:" Brain Drain Phenomenon in Western Balkan Countries with Special Emphasis in Kosovo, Macedonia and Albania" published at Journal of Economics and Sustainable Development, Vol.9, No.24, 2018

Prof.Asoc.Dr. Shaip Bytyçi, Dean of Faculty of Economics, AAB College, Kosovo, Pristina. 